\title{
ANALYSIS OF THE INFLUENCE OF EXTERNAL AND INTERNAL ENVIRONMENTAL FACTORS ON BUSINESS PERFORMANCE: A STUDY ON MICRO SMALL AND MEDIUM ENTERPRISES (MSMES) OF FOOD AND BEVERAGE
}

\author{
Ontorael Rizal ${ }^{*}$, Suhadak, Mawardi Mukhammad Kholid \\ Department of Business Administration, Faculty of Administrative Science, \\ University of Brawijaya, Indonesia \\ *E-mail: ontoraelrizal@gmail.com
}

\begin{abstract}
This study aimed to analyze and explain the influence of external environmental factors on internal environmental factors, along with the influence of external and internal environmental factors on business performance. This research was an explanatory research, using the questionnaire as the primary data and appointing the owners/managers of the enterprises as the object of the research. The total sample of this research was 108 respondents of MSMEs in the sector of food and beverage that were registered in the Office of Cooperatives, SMEs, Industries, and Trades of Batu City. The data analysis of this research indicated that external environmental factors had a positive and significant influence on internal environmental factors. Similarly, external and internal environmental factors also had a positive and significant influence on business performance.
\end{abstract}

\section{KEY WORDS}

External environmental factors, internal environmental factors, business, performance.

Micro Small and Medium Enterprises (MSMEs) have an important role in the national economic development and growth in all countries, not only in developing countries but also in developed countries. In addition to its contribution to gross domestic product (Tambunan 2008), MSMEs also play a role in employment, income making, and community economic movement. In Indonesia, MSMEs have a significant role in national economic development. MSMEs can be accessed as a rescuer in the national economic recovery because MSMEs can survive and thrive in the storms of economic crisis since 1998 (Utami and Lantu, 2014).

The development of Micro Small and Medium Enterprises (MSMEs) in Indonesia is one of the priorities in national economic development. This is because businesses become the backbone of people's economic system, which is to not only reduce the gap issues among income groups and business actors, or intended for poverty alleviation and labor absorption (employment). Moreover, its development is able to intensify the economic basis and give a significant contribution to improving the regional economy and national economic resilience. These conditions and facts are in line with the results of the small empirical research conducted by Demirbag et al. (2006), indicating that the success of small and medium enterprises has a direct impact on the economic development in both developed and developing countries. Micro Small and Medium Enterprises (MSMEs) have the ability to create cooperation with a minimum cost. They are pioneers in the world of innovation and have a high flexibility that enables the businesses to meet the consumers' needs.

The contribution of Micro Small and Medium Enterprises (MSMEs) to the national economy can be seen from several aspects, including from the aspects of business units, labor absorption (employment), and the contribution of Gross Domestic Product (GDP). Based on the data published by the Ministry of Cooperatives and Small and Medium Enterprises in 2013, the contribution of MSMEs reached 57.895 .721 or $99.99 \%$ of the total number of business units. If reviewed from the aspect of labor absorption (employment), the contribution of MSMEs in 2013 amounted to 114,144,082 people or approximately $96.99 \%$. Meanwhile, the contribution of Gross Domestic Product (GDP) in 2013 amounted to $5,440,007.9$ billion or $60.34 \%$. The data suggest that the MSMEs sector is one of the important pillars of the national economy. 
Despite having a very important role in the economy of Indonesia, Micro Small and Medium Enterprises (MSMEs) still face various external and internal issues such as: complex legal and regulatory constraints, lack of access to external financing, low human resource capacity, lack of management skills and training, and low technological capacity. This is in line with the opinion of Urata (2000), stating that the problems faced by small businesses can be grouped into two, namely financial and nonfinancial problems (business management). The financial problems include (1) lack of compatibility (mismatch) between available funds and the funds which can be accessed by small businesses; (2) the absence of a systematic approach to funding small businesses; (3) high transaction costs, caused by complicated credit procedures that take a lot of time while the amount of credit disbursed is very small; (4) lack of funds access to formal fund sources, either caused by the absence of banks in remote areas or the inadequate information; (5) high interest on loans for investment and working capital; (6) the large number of small businesses that have not been bankable, either due to the lack of transparent financial management or lack of managerial and financial capabilities. In another side, the non-financial problems (business management) include: (1) lack of knowledge of production technology and quality control, caused by the lack of opportunities to follow technological developments and lack of education and training; (2) lack of marketing knowledge, caused by the limited information on market that small businesses can reach, and limited number of small businesses that can provide products/services in accordance with market demands; (3) limitations and lack of skilled and creative human resources; and (4) lack of small businesses' understanding of accounting and finance.

Based on the problems stated above, MSMEs should be ready and prepared in capturing every opportunity as well as develop it optimally. If viewed from the existing perspective, the business opportunities must certainly be supported with a good performance by companies. Glencey (1998) defined that a performance refers to the level of achievement or attainment of a company within a certain period. The performance of a company is highly crucial for the development of the company. The company's goal is to maximize the value of the company reflected in various performance measures. The performance of a small business can be seen from the profitability and growth of the level of sales.

Jauch and Glueck (1998) explained that performance is the level of achievement or attainment of a company within a certain period. A company's performance is very influential on the development of the company. The company objectives, including: to remain standing or exist (survive), to gain profit (benefit), and to be able to develop or grow (growth), can be achieved if the company has a good performance. The performance of a company can be seen from the level of sales, profit levels, payback (return on capital), turnover rates, and market share achieved. One of the factors that must be implemented before formulating the goals and strategies applied in a company is environmental analysis and diagnosis. It is difficult for corporate leaders to know the problems faced until it can eventually lead to ineffective strategy formulation.

An effective planning serves to anticipate the negative things occurring or try to lead the environment to a favorable direction. The environmental analysis carried out commonly includes two things: the analysis of the external environment producing the images of opportunity and threat that will be faced by a company and the analysis of the internal environment creating the images of strength and weakness owned by a company. There are many factors affecting the achievement of a small company, including internal and external environmental factors. The success of the company depends on the company capability to manage these two factors through the analysis of environmental factors as well as the formation and implementation of business strategy. Internal challenges for MSMEs, especially in its development, cover a broad aspect of improving the quality of human resources, organizational-technological management capabilities, entrepreneurial competence, wider access to capital, transparent market information, other production input factors, and a healthy business climate that support innovation, entrepreneurship, business practice and fair competition. The increased value of entrepreneurship, marketing, and technological skills, as well as financial management will certainly improve the achievement 
or performance of the business. Similarly, the success of external factors, including social networks, legality, government support, coaching, technology, and access to information will be achieved if there is a correspondence between external and internal factors through the application of appropriate means.

Based on the background and previous studies, the researcher has been interested and intended to examine the influence of external and internal environmental factors on business performance. This research was conducted on food and beverage MSMEs located in Batu City. The purpose of this study was to analyze and explain what factors that might affect business performance and what the impacts are given from the influence of external and internal environmental factors on business performance.

\section{THEORETICAL REVIEW}

Definitions and Characteristics of MSMEs. Law No.20 of 2008 on Micro Small and Medium Enterprises has provided a clear definition of each business. It is written in the Act about who will carry out the business, capital limitations, and annual sales results. It is also explained that a micro business refers to a productive business conducted by an individual and/or business entity (enterprises) in accordance with the criteria of micro business as regulated in the Law. In contrast, small businesses are stand-alone economic enterprises, not a subsidiaries or branches of medium-sized or large-scale business, done by an individual and/or business entity. Furthermore, medium-sized businesses are independent economic enterprises, not subsidiaries or branches of companies and not cooperating with small or large business entities with the total assets and turnovers as stipulated in the Law. Micro Small and Medium Enterprises (MSMEs) are business units that continue to develop until now. According to Law No.20 of 2008, Micro Small and Medium Enterprises (MSMEs) aim to grow and expand its businesses in order to build a national economy based on a just economic democracy. In Indonesia, there are different views on the definition of MSMEs based on different perspectives such as the amount of assets/capital or the number of employees. Based on Law No.20 of 2008 and the Central Bureau of Statistics (BPS), the characteristics of MSMEs can be summed up as follows:

Table 1 - The Characteristics of MSMEs

\begin{tabular}{|c|c|c|c|}
\hline \multirow{2}{*}{$\mathrm{n} / \mathrm{n}$} & \multicolumn{2}{|c|}{ Law No.20 of 2008 } & BPS \\
\cline { 2 - 4 } & Total Net Worth/year & Total Sales/Year & Number of Employees \\
\hline Micro & $<$ Rp. 50.000 .000 & $<$ Rp. 300.000 .000 & $<4$ employees \\
\hline Small & Rp. $50-$ Rp. $500 \mathrm{M}$ & Rp. $300-$ Rp. $2,5 \mathrm{M}$ & $5-19$ employees \\
\hline Medium & Rp. $500-$ Rp. $10 \mathrm{M}$ & Rp. $2,5 \mathrm{M}-$ Rp. $50 \mathrm{M}$ & $20-99$ employees \\
\hline
\end{tabular}

Source: Law No. 20 of 2008 and BPS (2017).

Corporate Environment. Jones (1995) explained that corporate environment is a series of resources that surrounds the company's organization to support the business success in facing competition. Strategic managers should be involved in environmental observations, both of the internal environment (to know the strengths and weaknesses) and the external environment (to see opportunities and threats that may occur). Crijns and Ooghi (2000) revealed that each stage of company growth is the result of the two environments where the company does its business, namely the internal and external environments that affect each other. The important external factors influencing the company growth are industry, market, competitors, and economic climate. While the internal factors that affect the growth of company are the characteristics of entrepreneurs. This is in line with the research conducted by Bouazza, et al. (2015), stating that the growth of SMEs in Algeria is hampered by several interrelated factors, including the factors of the business environment that are beyond the control of SMEs and internal factors of SMEs.

External Environment. Wheelen and Hunger (2001) described the external environment as a power outside the company that has direct influence and interest to the company, such as governments, trade unions, creditors, trade associations, shareholders, special interest 
groups, and the communities surrounding the company. This is in line with the views of Pearce and Robinson (2014) and David (2009), stating that external environment is factors beyond the control of a company that may affect the success of the company. Furthermore, the results of the research conducted by Alkali and Isa (2012) indicated that external environmental factors consist of access to capital and government supports, which have a positive and significant influence on company performance. This suggests that access to capital is highly important in running and developing business along with its impact on company performance. In order to achieve the goals of a business, a company needs capital to finance the business well. The statement is in accordance with the research results of Bouazza et al. (2015), stating that some factors, including unhealthy competition of the informal sectors; complicated procedures and bureaucracy; burdensome laws, policies and regulation; inefficient tax systems; lack of access to external financing; and low human resource capacity are the main external environmental factors, consisting of economic, political, technological, and socio-cultural factors, have a positive and significant effect on organizational performance.

Internal Environment. Pearce and Robinson (2014) argued that the experiences of large and small companies show that an in-depth environmental understanding and internal company assessment are very crucial in developing a company's success. Considering that the internal environment encompasses various aspects within a company, the analysis of the internal environment should consider the strengths that laid the foundations for corporate strategy. Wheelen and Hunger (2001) divided the internal environment into three important categories: 1) structures - the way in which a company is organized in terms of communication, authority, and workflow; 2) cultures - the pattern of beliefs, expectations, and values shared with the members of an organization in which organizational norms specifically conjure up and define the acceptable behaviors of the members of top managers to operational employees; and 3) resources - the assets in the form of raw materials for production process of goods/services contained in the organization of the company. In another side, David (2009) divided the internal forces into six important categories, consisting of the functions of management, marketing, financial/accounting, production and operation, research and development, and management information system. If the various things in the internal environment are done well, it will be very potential that the success of a strategy can be achieved as desired by the company (Pearce and Robinson, 2014).

Duncan (1972) and Williams (2009) in Abolaji and Oni (2015) stated that the internal environment of an organization consists of factors related to the firm that influences its ability to achieve the stated objectives, and develop as well as implement feasible plans, which consequently contribute to its performance. The internal environment can also be described as internally controlled forces operating within the organization itself that has a direct impact on organizational performance. This includes financial resources, information and knowledge, corporate capabilities, incentives, organizational demographics such as the size of inter-institutional relationship, corporate objectives, and employee skills (Freeman and Reid, 2006 in Abolaji and Oni, 2015). Meanwhile, the research results of Bouazza et al. (2015) indicated that entrepreneurial characteristics, low managerial skills, lack of marketing skills, and low technological capacity are the major environmental factors affecting the growth of SMEs in Algeria.

Business Performance. Jauch dan Glueck (1988) described that performance refers to the level of achievement or attainment of a company within a certain period. The performance of a company is crucial in the development of the company. The objectives of a company, including: to remain standing or exist (survive), to gain profit (benefit), and to be able to develop or grow (growth), can be achieved if the company has a good performance. The performance of a company can be seen from the level of sales, profit levels, payback (return on capital), turnover rates, and market share achieved.

Researchers have proposed the sales growth, employment growth, income growth, and market share growth as the most important measurement of small enterprises performance (Kim and Choi, 1994; 1996; Luo, 1999; Miles et al. 2000; Hadjimanolis 2000). This is also based on an argument stating that growth is a more appropriate and accessible 
indicator than financial performance indicators. Another alternative opinion is that performance is multidimensional and therefore it is useful to integrate different dimensions of performance in an empirical study (Lumkin and Dess, 1996). It is appropriate to view financial performance and growth as different aspects of performance, in which each has an important and unique information. Together, financial growth and performance provide a wider description of the company's actual performance rather than using individual measurements. In this study, performance measurements were performed using nonfinancial measures.

\section{CONCEPTUAL FRAMEWORK AND HYPOTHESIS}

This study actually was aimed to explain the external and internal environmental factors influencing the success and performance of companies, particularly Micro Small and Medium Enterprises. Both external and internal environmental factors can directly affect the performance or success of businesses, and indirectly affect the success of Micro Small and Medium Enterprises (MSMEs).

Based on the theoretical review and the adjustment with the Micro Small and Medium Enterprises examined, this research used the variable of internal environment factors, including: entrepreneurship characteristic factor, management capacity, marketing skill, and technology capacity. Meanwhile, the external environmental factors include legal and regulatory framework, access to external financing, and human resource capacity. These factors are considered relevant in conducting the study on Micro Small and Medium Enterprises (MSMEs) in Batu City.

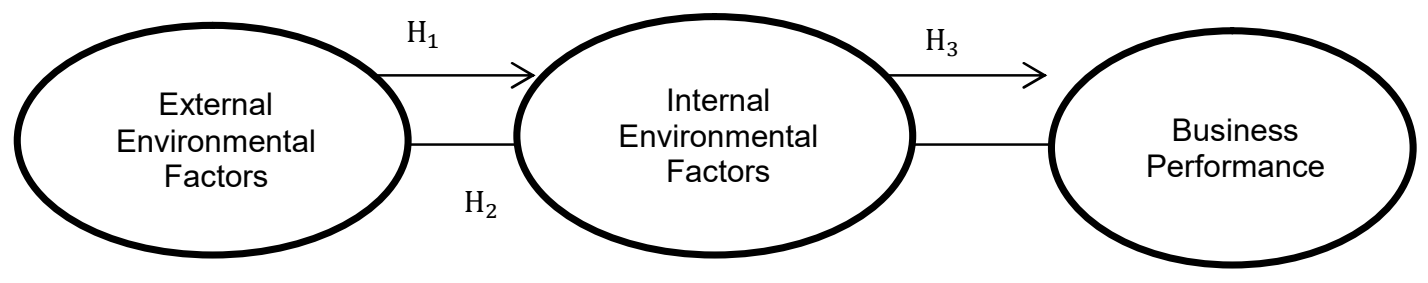

Figure 1 - Model of Conceptual Framework and Hypothesis

Based on Figure 1, the statements of hypothesis used in this research are as follows:

$\mathrm{H} 1$ : External Environmental Factors have a significant effect on Internal Environmental Factors;

H2: External Environmental Factors have a significant effect on Business Performance; H3: Internal Environmental Factors have a significant effect on Business Performance.

\section{METHODS OF RESEARCH}

The type of this research was explanatory with quantitative approach. The number of samples examined was 108 MSMEs in the field of food and beverage in Batu City, Jawa Timur (East Java) Province, Indonesia, by having the owners/managers as the target respondents. The source of data obtained in conducting this research derived from primary and secondary data. The primary data were directly obtained based on the respondents' answers on the questionnaires distributed to the MSMEs examined. The measurements were made using Likert Scale, in which the respondents' answers of each statement were given a score of 5 (for the highest value) up to 1 (for the lowest value). The questionnaires obtained from the overall food and beverage MSMEs have been met and adjusted with the needs of the research, thus it was feasible to be forwarded to the stage of data analysis.

The technique of data analysis used in this research was Partial Least Square (PLS) with the analysis tool of SmartPLS 3.0. The data analysis with PLS consists of two stages: evaluation of measurement model (outer model) and evaluation of structural model (inner model).The outer model evaluation consists of three criteria, namely convergence validity, 
discriminant validity and composite reliability. In the calculation of convergent validity criterion, the minimum loading factor was 0.50 (Chin, in Ghozali, 2011). Discriminant validity was measured by comparing the square root of AVE for each construct with the correlation value between constructs in the model. Good discriminant validity, namely the square root of AVE, for each construct was greater than the correlation between constructs in the model. If the value of AVE root is higher than the correlation value between the constructs, then it means that good discriminant validity has been achieved. The next test for analyzing the outer model was observing the construct reliability of the latent variable measured by two criteria, namely composite reliability and Cronbach alpha of the indicator block measuring the construct. The construct was considered reliable if the values of composite reliability and Cronbach alpha value are above 0.70 . Table 2 shows the output of composite reliability and Cronbach alpha.

Table 2 - Composite Reliability and Cronbach Alpha

\begin{tabular}{|c|c|c|c|}
\hline Variable & AVE & Composite Reliability & Cronbachs Alpha \\
\hline $\mathrm{X} 1$ & 0.7819 & 0.9149 & 0.8618 \\
\hline $\mathrm{X} 2$ & 0.7920 & 0.9383 & 0.9123 \\
\hline $\mathrm{Y}$ & 0.8742 & 0.9329 & 0.8561 \\
\hline
\end{tabular}

Source: PLS, 2017.

Note: X1= External Environmental Factors, X2= Internal Environmental Factors, $Y 1=$ Business Performance.

Based on the Table 2, it can be seen that the outer model had met the criterion of good discriminant validity with the AVE value above 0.5 and the construct was declared reliable because it had complied the value of composite reliability and cronbach alpha above 0.70 .

Moreover, the inner model or structural model testing was performed to see the relationship between the construct of significance value and $R$-square of the research model. The structural model was evaluated by using $R$-square for the dependent construct of t-test as well as the significance of the structural path parameter coefficients.

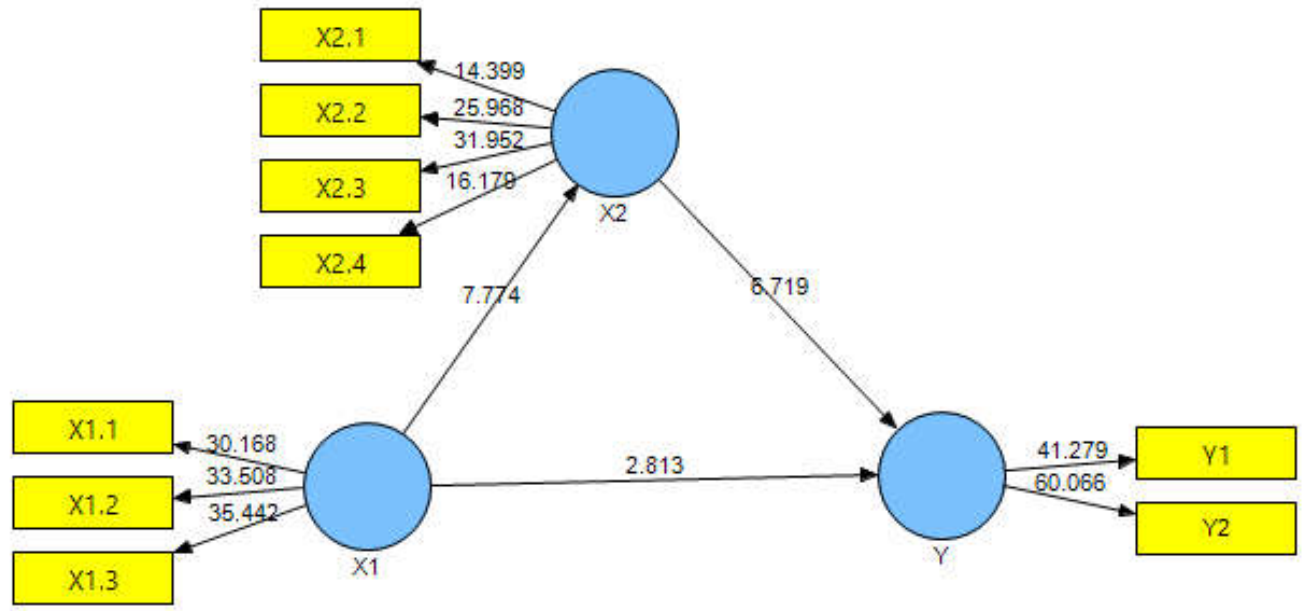

Source: SmartPLS (2017).

Figure 2 - Structural Model (Inner Model)

The testing on the structural model was done by knowing the R-square, which is the goodness-fit model testing.

Table 3 - R-Square

\begin{tabular}{|l|l|}
\hline Variable & R Square \\
\hline $\mathrm{X} 2$ & 0.4265 \\
\hline $\mathrm{Y}$ & 0.6046 \\
\hline
\end{tabular}

Source: PLS, 2017. 
Based on the table above, the value of R-square for Internal Environmental Factors was 0.4265 . The R-square value indicated that $42.65 \%$ of Internal Environmental Factors variable (X2) could be influenced by internal environmental factors (X1). And the rest of $57.35 \%$ was influenced by other variables out of what was examined. The R-square value on Business Performance of 0.6046 showed that Business Performance variable ( $\mathrm{Y}$ ) was influenced by External Environmental Factors (X1) and Internal Environmental Factors (X2) $(60.46 \%)$, while the rest of $39.54 \%$ was influenced by other variables out of what was examined.

Evaluation of PLS model was done with $Q^{2}$ predictive relevance used to measure how good the value of observation produced by the model and also its parameter estimation. The value of $Q^{2}$ predictive relevance can be obtained by this equality:

$$
\begin{aligned}
& \text { Value of } Q^{2}=1-\left(1-R^{2}\right) \times\left(1-R^{2}\right) \\
& Q^{2}=1-(1-0.4265) \times(1-0.6046) \\
& Q^{2}=1-0.02267 \\
& Q^{2}=0.7732
\end{aligned}
$$

Based on the calculation, the model has a predictive relevance because the value of $Q^{2}$ obtained was > 0, that was 0.7732 and it belongs to strong category (Ghozali, 2011).

\section{RESULTS AND DISCUSSION}

In PLS, the statistical testing of each relationship hypothesized was done by using simulation. In this case, a method of bootstrap was performed on the sample. The testing with bootstrap method was intended to minimize the abnormalization problem of the data research. The results of the testing with bootstrapping of the PLS analysis is as follows:

Table 4 - Path Coefficient (Mean, STDEV, T-Values)

\begin{tabular}{|c|c|c|c|}
\hline $\begin{array}{c}\text { Variable } \\
\text { Relationship }\end{array}$ & $\begin{array}{c}\text { Original } \\
\text { Sample (O) }\end{array}$ & $\begin{array}{c}\text { Standard Deviation } \\
\text { (STDEV) }\end{array}$ & $\begin{array}{c}\text { T-Statistics } \\
(|\mathrm{O} / \mathrm{STERR}|)\end{array}$ \\
\hline $\mathrm{X} 1->\mathrm{X} 2$ & 0.6531 & 0.084 & 7.7737 \\
\hline $\mathrm{X} 1-\mathrm{Y}$ & 0.2398 & 0.0853 & 2.8128 \\
\hline $\mathrm{X} 2->\mathrm{Y}$ & 0.5994 & 0.0892 & 6.7187 \\
\hline
\end{tabular}

Source: PLS (2017).

The estimated parameter significance provided a very beneficial information on the relationship between the variables of the research. The standard used in examining the hypothesis was the value existing in output result for inner weight. The hypothesis testing could be conducted by comparing t-statistic to t-table. T-table could be obtained from 108 respondents from whom t-table of 1.960 was obtained. Thus, it can be concluded that the analysis results of the hypothesis testing are that $\mathrm{H} 1, \mathrm{H} 3$, and $\mathrm{H} 3$ are accepted.

Inferential Statistics Analysis. The results of the hypothesis testing with SmartPLS that has been done in the previous indicate that all of the 3 hypotheses proposed in this research are accepted. Here is the detail explanation:

Effect of External Environmental Factors on Internal Environmental Factors. The results of the statistical tests showed that the t-statistical value of the influence of external environmental factors on internal environmental factors was 7.7737. The test results showed that the t-statistics $>1,960$. Meanwhile, the coefficient of external environmental factors path and internal environment factors was equal to 0,6531 , meaning that external environment factors had a positive and significant effect of internal environment factors. That is, the better external environmental factors will influence the business performance through internal environmental factors. The results of this study are in line with the theory put forward by Pearce and Robinson (2008), stating that external environment is a factor outside the control of a company which can influence the choice of direction and action, organizational structure and internal processes of the company. The results of this research and theory are 
also reinforced by the results of previous research, stating that a good external environment will positively influence the internal environment and the results will have an impact on the business performance improvement (Minzu, 2010). Similarly, the results found by Wilkinson (2002) and Bouazza, et al. (2015) suggested that external environmental factors have an effect on internal environmental factors and also on the growth and performance of SMEs. That is, if the external and internal environmental factors can be utilized and managed optimally, it will be an opportunity for MSMEs to develop the business and eventually result in a success that is the improved performance of the business itself.

Effect of External Environmental Factors on Business Performance. The results of the statistical test with SmartPLS which examined the relation between external environment factor to business performance showed that the path coefficient test was 0.2398 and t-statistic was equal to 2,8128 which was bigger than t-table $(1,960)$ and significant or $p \leq 0,05 \%$. These results indicated that external environmental factors had a significant positive effect on business performance. That is, the better the external environment is, the better the business performance will be. It shows that MSMEs Food and Beverage in Batu City have an external environment that supports the business performance. The greater support from the government in the form of regulation/pro-business policy could make the access to external funding (in this case, the easiness in obtaining capital from financial institution/banks and capacity of skilled human resources) have an impact on the improvement of Food and Beverage business performance in Batu City. The results of this research support the previous studies, showing that external environmental factors affect business performance (Banham, 2010; Alkali \& Isa, 2012; Bouazza, et al., 2015; and Kraja \& Osmani, 2015).

Effect of Internal Environmental Factors on Business Performance. The results of the third hypothesis test regarding the influence of the internal environmental factors on business performance showed that the path coefficient of 0.5994 and the t-statistics of 6.7187 were greater than t-table $(1,960)$ and significant or $p \leq 0.05 \%$. These results indicated that internal environmental factors had a significant positive effect on business performance. It showed that MSMEs Food and Beverage in Batu City had a good internal environment in supporting business performance. Therefore, the better the owners/managers of the businesses execute the management capacity, the product promoting, and the utilization and use of technology in improving production efficiency, the more positive the impact on the improvement of Food and Beverage business performance in Batu City will be. The results of this study are in line with the results of the previous studies, revealing that internal environmental factors have a positive and significant influence on business performance (Sidika, 2012; Aylin, et al. 2013; and Kraja \& Osmani, 2015; Abolaji and Oni, 2015; Bouazza et Al., 2015). The results indicate that internal environmental factors can improve business performance.

Research Limitations. The researcher realizes that, in the implementation of this research, there are some obstacles and limitations, including:

The data used in this research were the data obtained from the owners/managers of food and beverage MSMEs, in which the respondents' answers considered appropriate with the respondents' measures possibly have not yet reflected the variables that have not been studied. Nevertheless, the researcher had tried to give the appropriate statements and made it easier for the respondents to understand them, so that the best answers to reflect the variables studied (external environmental factors, internal environment factors, and business performance) could be achieved.

This research took only one type of sectors of Micro Small and Medium Enterprises namely sector of food and beverage business, so the generalization result of this research is limited.

The lack of theoretical review or reference of previous studies related to the effect of external environment factors on internal environment factors of MSMEs has made the researcher difficult to relate the results of this research with the previous studies. 


\section{CONCLUSION AND SUGGESTIONS}

The conclusions that can be drawn from the results of the analysis and discussion in the previous section, as well as the relevance to the research objectives, are as follows:

1. The results of the analysis indicate that external environmental factors have a positive significant effect on internal environmental factors on MSMEs of Food and Beverage in Batu City. Legal and regulatory framework, access to external funding, and human resource capacity are the factors of the external environment found to have a significant influence on internal environmental factors.

2. The external environmental factors have a significant and positive influence on the business performance of Food and Beverage MSMEs in Batu City. The factors found to affect the business performance include the legal and regulatory framework, access to external funding, and human resource capacity. The better the management of external environmental factors is, the greater level of business performance of Food and Beverage in Batu City will be.

3. The results of the analysis indicate that the internal environmental factors positively and significantly affect the business performance in MSMEs of Food and Beverage in Batu City. The entrepreneur characteristics, management capacity, marketing skills and technological capacity are the factors of internal environment that are found to have a significant effect on the business performance.

Based on the conclusion section, here are some suggestions expected to be carried out for both practical interests and further research development:

1. For the government, the determined regulations should be directed to policies that are pro-business of Micro Small and Medium Enterprises (MSMEs). The facilities and mediation conducted by the government in providing convenience to entrepreneurs should be focused on the ease of access to finance/capital resources, technical and managerial training, ease of business license attainment, availability of business centers/locations and market information.

2. For owners or managers of Micro Small and Medium Enterprises (MSMEs), they need to increase the competence of entrepreneurship in order to be able to face competition. With a maximum competence, it is expected that MSMEs can achieve better performance so that they can still exist in any environmental conditions.

3. For further researchers, it is expected that the future studies can be done with a developed model, by adding other variables that can influence the performance of food and beverage MSMEs, as well as examine different objects.

\section{REFERENCES}

1. Abolaji, O. \& Oni, I. (2015). The Effect of Internal Environment on the Performance of Small and Medium Scale Enterprise in Kano Metropolis.International Journal of Management and Commerce Innovations. ISSN:2348-7585, Vol.3.

2. Alkal, M. and Isa, A.H.M. 2012. Assessing the Influence of External Environmental Factors, on the Performance of Small Business Manufacturing enterprises in Bauchi state, Nigeria. Vol 4, No. 7

3. Banham, H.C. (2010). External Environmental Analysis For Small and Medium Enterprises (SMEs). Journal of Business \& Economics Research, Vol 8, No 10.

4. Bouazza, A.B., Ardjouman, D., Abada, O. (2015). Establishing the Factors Affecting the Growth of Small and Medium-sized Enterprises in Algeria. American International Journal. Vol. 4, No. 2.

5. Crijns, H. \& Ooghi, M. 2000, Growth Paths of Medium Sized Entrepreneurial Companies. De Vlerick School Voor Management, University of Ghent.

6. David, F.R. 2009. ManajemenStrategis. Konsep, Edisi 12, Terjemahan oleh Dono Sunardi, Salemba Empat, Jakarta.

7. Demirbag, M., Tatoglu, E., Tekinkus, M. and Zaim, S. 2006. An Analysis of the Relationship Between TQM Implementation and Organizational Performance: Evidence 
From Turkish SMEs.Journal of Manufacturing TechnologyManagement, Vol. 17 No. 6 , pp. 829-47.

8. Ghozali, I. 2011.Structural Equation Modeling Metode Alternatif dengan Partial Least SquareEdisi 3". Badan Penerbit Undip.,Semarang.

9. Jauch L.R. and Glueck W.F. 1998. Business Policy and Strategic Management, McGraw Hill, New York.

10. Jones, G.R. 1995. Organizational Theory: Text and Cases. Addision-Wesley Publishing Company, Inc. New York.

11. Munizu, M 2010. Pengaruh Faktor-Faktor Eksternal dan Internal Terhadap Kinerja Usaha Mikro dan Kecil (UMK) di Sulawesi Selatan.Jurnal Manajemen dan Kewirausahaan, Vol. 12. No. 1, 33-41.

12. Pearce, J.A. \& Richard, R.B. 2008. Strategic Managemen. Penerbit Salemba Empat. McGraw Hill. Jakarta

13. Tambunan Tulus, 2008. SME Development, Economic Growth, and Goverment Intervention in A Developing Country: The Indonesian Story. Journal of International Entrepreneurship. Vol. 6: 147-167.

14. Urata, S. 2000. Policy Recommendation for SME Promotion in the Republicof Indonesia. Japan International Coorporation Agency.

15. Utami, R.M. and Lantu, D.C. 2014. Development Competitiveness Model For SmallMedium Enterprises among the Creative Industri In Bandung. Procedia-Social and Behavioral Sciences Vpl. 115 305-323.

16. Wilkinson, B. 2002. Small, Micro and Medium Enterprise Development:Expanding the Option for Debt and Equity Finance. Financial Sector Workshop, National Economic Development and Labour Council (NEDLAC). Johanesburg, South Africa, Iris, April 6.

17. Wheelen, T. L. \& Hunger, J D. (2001). Strategic Management and Business Policy (10th ed). New Jersey: Prentice-Hall International. 